\title{
EUROPEAN ARREST WARRANT: APPEARANCE AND PREFERENCES FOR FULFILLMENT
}

\author{
Marin Petkov ${ }^{1}$ and Dragomir Krastev ${ }^{2}$, \\ ${ }^{1}$ Assoc. Professor, Ph.D., National Military University, Veliko Tarnovo, Bulgaria, \\ marin_5kov@abv.bg \\ ${ }^{2}$ Assoc. Professor, Ph.D., National Military University, Veliko Tarnovo, Bulgaria, \\ drago.krastev@gmail.com
}

\begin{abstract}
The European Seascape of the Restricted Area (ERA) and the decision of the Council of Europe of the European Union (2002/584 / TAC) from 13 June 2002, was published in the Official Gazette of the European Community for 18 July 2002. European arrest warrant is in charge of the European Union before the moment of the convention for extradition, (без attach) between the European Union and the formal nationality Extradition procedure (без from the procedure) for the betrayal among the EU Member States and the EU based on European arrest warrant. The problem is based on the principle of reciprocal trust between the body on the burdens-members and on the reciprocal recognition of the publication of the act of the assembly from the punishable body on the one-year-old member and addressing it to the authorities so that the body is a member of the EU member-state.
\end{abstract}

Keywords: extradition, European Union, European arrest warrant, mutual trust, crimes.

\section{INTRODUCTION}

When European Commission publishes its own proposal on the Decision for the European arrest warrant, as well as in the period of speaking on the unconditional cessation, the citizen on the Member States of the EU is all still strongly influenced by the terrorist act of 11 September 2001. At the time of the introduction of the ball, which is more important than the battle with international terrorism and the organized crime, this is the main priority and is finalized in the Decision for the European arrest warrant. It is given for approval.

\section{EUROPEAN ARREST WARRANT. APPEARANCE AND PREFERENCES FOR FULFILLMENT}

The European arrest warrant /EAW/ is based on the principle of the qualitative characteristics, as it is partly partially preempted by a double punishable, limited to national disqualifications, as regards citizens, practice and seals, are mutually recognized at the time of the act and are free to move within the framework of the EU.

The solution for EAW was termed rambling out of the use of the term „extradition“, as well as the thoughts of 
„Requesting State“ and „Requested State", traditionally for the extradition production, according to the EKE of 1957 and the 1995 and 1996 conventions. Instead of you, during with the term" betrayed "by the person, „publishers“, „executing“ the judicial body.

Niko Kaiser and Oto Lagodni think that EAW is a form of extradition. The opinion of Todor Kolarov was the opposite. The difference is in the extradition, which is characterized with two phases - judicial and administrative. The decision is taken in the phase of the arbitration, the reason for refusing a sarcastic determination, and the decision is final.

Spoiled by Pavlina Panova, the products of the news are in the air for internationally punishingly cooperation and some radicals bringing in the Decision for EAW is determined by the national government, which is next to the decision for the betrayer on the face of the person valid at EAW. According to the decision for the "betrayer" of the flop from the "judicial body" and on the definition of the exclusion of the field on the political power, the power is betrayed.

With EAW element for a pre-estimate for political considerations, is typical for extradition to the administrative phase, missed. The scarecrow is the only one in compliance with the procedural rules, some condition for free movement at the decision in the framework of the EU. Decision of EAW speaks for publishers and plays the role of a "judicial body". The relationship does not develop on intercurrently, as with extradition production, but between the organizations in the framework of the supranational structure, like the EU.

The College dealt with two general issues related to the application of the EAW. The first issue was linked to the application of Article 3(2) Council Framework Decision 2002/584/JHA on the European Arrest Warrant (FD on the EAW) (grounds for mandatory non-execution of the EAW). The issue concerned the gathering of legal and practical information on the consequences of the non-removal of a warrant from the Schengen Information System (SIS) II and INTERPOL databases in a case in which a person subject to an EAW or extradition request was finally dealt with in criminal proceedings on the same factual basis in another Member State. The second general issue concerned the gathering of practical and legal information on the implementation in the Member States of Article 24 FD on the EAW (postponed or conditional surrender), namely whether this provision has been fully implemented and, if so, the conditions that have been imposed by the Member States' judicial authorities in allowing such 'temporary surrender' to take place. Eurojust continued to play a key role in improving cooperation on criminal matters between the Member States (Article 3(1)(b) of the Eurojust Decision), particularly by: i) facilitating the execution of EAWs and the exchange of information between national authorities; ii) establishing lines of communication between national authorities with a view clarifying diverging applications at national level of provisions of the FD on the EAW; iii) clarifying the legal requirements of both issuing and executing authorities; iv) advising on the drafting of EAWs both before their issuance and at the time of their redrafting; and $v$ ) coordinating the issuance and execution of EAWs and contributing to the prevention of possible conflicts of jurisdiction. Some of the legal and practical issues encountered by Eurojust in its EAW casework in 2014 concerned:

Difficulties linked to differing interpretations and practical application of the speciality rule (Article 27, paragraphs 2, 3(g) and 4 FD on the EAW) in cases in which, further to a surrender, a third Member State requests the issuing Member State to listen to the surrendered person, and this request is refused on the basis that consent for carrying out this 'interview of the suspect' should be sought from the executing Member State, while for the third Member State the 'interviewing' of a suspect does not amount to 'prosecution', and thus consent is not considered to be required;

Additional issues associated with the speciality rule (Article 27(4) FD on the EAW) in cases in which, further to a surrender, the issuing Member State requests the consent of the executing Member State under Article 27(4) FD on the EAW to enable the former to urgently serve (time bar was approaching) an indictment on the surrendered person on a separate unrelated offence and be allowed to commit that person to trial on that separate charge; consent having been refused, discussions are ongoing with a view to ascertaining the means at the disposal of the issuing Member State to enable at least the suspension of the time bar for prosecution;

Issues linked to the requirement under the law of some Member States to listen to the requested person before they can issue an EAW, and the difficulties arising when the location of the person is known by both the Member State running the investigation and the Member State in which the person is located but cannot yet be arrested;

Different interpretations of the type of guarantee foreseen under Article 5(3) FD on the EAW (return of person to executing Member State to serve the sentence imposed in the issuing Member State) required by the executing Member State, and a related dispute over which Member State (issuing or executing) should 
subsequently bear the cost of the return after trial (different views on possible applicable legal basis: FD on the EAW, Council Framework Decision 2008/909/JHA on the application of the principle of mutual recognition to judgements in criminal matters imposing custodial sentences or measures involving deprivation of liberty for the purpose of their enforcement in the European Union);

Issues linked to withdrawal of an EAW if the reasons for the withdrawal are not clear to the executing Member State and substantial efforts and resources have already been put into the execution of the EAW;

Proportionality issue arising in an EAW issued for retrial concerning a minor offence; and

Issues related to protection of fundamental rights, namely whether prison conditions are adequate for a person suffering from mental desease, and the preparedness of the issuing Member State to provide additional information concerning guarantees relating to prison conditions.

Eurojust has also continued to develop its assistance to Member States in relation to competing EAWs (Article 16(2) FD on the EAW). Under this provision, Eurojust may be requested by the executing judicial authorities to provide advice on the place of surrender of a person who is the subject of EAWs issued by two or more Member States. In 2017, Eurojust was formally requested to provide such advice in four cases. Eurojust provided advice and expertise at an early stage, either through negotiation or direct contact with the concerned authorities at Eurojust coordination meetings. Coordination meetings provide a vital venue as they allow discussion of the state of play and existing problems in a case and agreement on strategy, such as the priority of EAWs and, in the event of parallel investigations and prosecutions for the same conduct. With regard to breaches of time limits in the execution of EAWs, Article 17(7) FD on the EAW provides that, in exceptional circumstances, if a Member State cannot observe the time limits provided for in Article 17, it shall inform Eurojust and provide the reasons for the delay. In 2017, 123 breaches of time limits were registered at Eurojust. Six of these cases required further action. For the fifth consecutive year, Ireland reported the largest number of breaches. Other cases were referred by the Czech Republic, Spain, Latvia, Bulgaria, Croatia, and the UK.

Since the Aranyosi and Căldăraru judgement of the CJEU of 5 April 2016, Eurojust has noted an increase in the number of EAW cases in which judicial authorities experienced difficulties with the execution of EAWs due to allegedly inadequate prison conditions in the issuing Member States. In February, the College held a thematic discussion, EAW and prison conditions, to exchange experience and best practice. During the discussion, participants also referred to the above-mentioned judgement and its impact on national cases, and examined prospects for further Eurojust support to national practitioners. In addition, in November, Eurojust hosted an expert meeting, Creating a tool to assess detention conditions, which was organised by FRA. National experts from 12 Member States, as well as representatives from FRA, the Commission, the EJN Secretariat and Eurojust, discussed the development of possible tools to assess detention conditions. The outcome of the discussion will be reflected in a FRA report. Eurojust also produced a Briefing Note on the Petruhhin Judgment (Case C-182/15) and the Role of Eurojust, published as Council doc. 15786/17 LIMITE. The purpose of this note is to inform the practitioners of the Member States of the consequences of the Petruhhin judgement and of the role that Eurojust can play in this regard. The briefing note summarises the judgement, mentions some of the main questions raised by the application of this judgement, and finally discusses Eurojust's possible role in this context.

\section{CONCLUSION}

The European arrest warrant is a first Instrument, in conjunction with the Act of Practice, practically adheres to the principle of mutual recognition at the decision of the judiciary, and so does the act on the EU under the format for the framework decision.

On the basis of the experience of Eurojust's National Desks in relation to the reporting of such breaches by national authorities, the Note touches upon the services that Eurojust can provide at operational and strategic level to encourage compliance by the Member States with their obligation to inform Eurojust of such breaches and the reasons therefore, and it addresses the main issues identified concerning these notifications.

Concerning the role of Eurojust, Consultative Forum members concluded that Eurojust has played, and should continue to play, a pivotal role in the application of the EAW, by

Improving mutual understanding of Member States' legal systems and stimulating and facilitating consultation between Member States;

Coordinating and providing national authorities with relevant legal information; and 
Providing assistance in the translation of EAWs. Another conclusion was that Eurojust's role as a centre of legal and practical expertise in the field of the EAW should be enhanced. Eurojust has also developed useful instruments that can help practitioners in complex EAW cases, e.g. the Eurojust Guidelines for Deciding on Competing EAWs and will continue to provide updated information on European case law, constitutional issues and recurring practical problems related to the application of the EAW (Hristov, 2018a, pp.61-67; Hristov, Radulov, Iliev, Andreeva, 2010a; Hristov, 2018b, pp. 183-186; Hristov, Ninov, 2018c, pp.316-323; Hristov, Naplatanova, 2018d, pp. 293-315; Hristov, 2017a, pp. 998-1004, Hristov, Georgiev, 2017b, , pp. 110 -113; Hristov, Georgiev, 2017c, , pp. 114-117; Hristov, Glushkov, 2018e, pp.582-588; Hristov, Glushkov, 2018f, pp. 187-193; Hristov, 2017d, pp. 821-829; Madanski, Georgiev, 2017e, pp. 4-13; Madanski, Georgiev, 2017f, pp. 43-51; Terziev, Madanski, Georgiev, 2017g pp. 748-753; Terziev, Madanski, Georgiev, 2017h pp. 743-747; Terziev, Madanski, Georgiev, 2017i pp. 923-927; Terziev, Madanski, Georgiev, 2017j, pp. 10511055; Terziev, Nichev, Bankov, 2016a, s.189-196; Terziev, Nichev, Bankov, 2016b, s. s.116-134; Terziev, Nichev, Bankov, 2016c, pp.12-21; Terziev, Nichev, Bankov, 2016d, str.119-128; Terziev, Nichev, Bankov, 2016e, str.129-146; Terziev, Nichev, Bankov, 2016e, str.129-146; Terziev, Nichev, Bankov, 2016f, str. 144185; Terziev, Nichev, Bankov, 2016f, str. 144-185; Terziev, Nichev, Bankov, 2016g, s.413-422; Terziev, Nichev, Bankov, 2016h, str.177-204; Nichev, 2017k, str. 121-128; Nichev, 2017l, pp. 129-135; Kanev, Terziev. 2017m; Kanev, Terziev, 2017n; Terziev, 2017o; Terziev, 2016i; Terziev, 2017p; Terziev, 2017q; Terziev, Vezieva, Arabska, 2016j; Terziev, Manolov, 2016k; Terziev, Minev, Sotirov, Ivanov, 2016l; Terziev, Kanev, 2017r; Terziev, Madanski, 2017s; Terziev, Madanski, 2017t; Terziev, Madanski, 2017u; Terziev, Madanski, Kanev, 2017v; Terziev, Madanski, Kanev, 2017w; Terziev, Madanski, Kanev, 2017x; Terziev, Madanski, Kanev, 2017y; Terziev, Madanski, Kanev, 2017z; Terziev, Nichev, 2016m; Terziev, Nichev, 2017).

\section{REFERENCE LIST}

Hristov, Neno. (2018a). Military Education as Possibility in Bulgaria. IJAEDU- International E-Journal of Advances in Education, Vol. IV, Issue 10, April 2018, pp.61-67.

Hristov, N., Radulov, I., lliev, P., Andreeva, P. (2010a). Prioritization Methodology for Development of Required Operational Capabilities. RTO-MP-SAS-081, 2010.

Hristov, Neno. (2018b). NATO Resilience, Deter and Professional Military Education. Proceedings of INTCESS 2018- 5th International Conference on Education and Social Sciences 5-7 February 2018Istanbul, Turkey, pp. 183-186.

Hristov, N, Ninov, M. (2018c). People's Character As a Prerequisite for the Albanian 'National Delay'. // 5th International Conference on Education, Social Sciences and Humanities, 2-4 July, 2018, ISBN: 978605-82433-3-0 316, pp.316-323.

Hristov, N, Naplatanova, G. (2018d). The Stereotypes of Military Towards Journalists and Work with Embedded Reporters in Missions and Operations Abroad. // 5th International Conference on Education, Social Sciences and Humanities, 2-4 July, 2018 - Dubai, ISBN: 978-605-82433-3-0, pp. 293-315.

Hristov, Neno. (2017a). Bulgarian Experience in the Development of Military Concepts. // IJASOSInternational E-Journal of Advances in Social Sciences, Vol. III, Issue 9, December 2017, pp. 9981004.

Hristov, N., Georgiev, M. (2017b). Offset implementation impact on technology transfer in Bulgaria. // International Scientific Journal "Internauka". Izdatel' OOO «Finansovaya Rada Ukrainy», Kiyev, № 10 (32), 2017, pp. 110 -113, ISSN 2520-2057 (Hristov, N., Georgiev, M. Offset implementation impact on technology transfer in Bulgaria. // International Scientific Journal "Internauka". Издатель ООО «Финансовая Рада Украины», Киев, № 10 (32), 2017, pp. 110 -113, ISSN 2520-2057).

Hristov, N., Georgiev, M. (2017c). Offset as an economic operation and a trade practice. // International Scientific Journal “Internauka”. Izdatel' OOO «Finansovaya Rada Ukrainy», Kiyev, № 10 (32), 2017, pp. 114-117, ISSN 2520-2057 (Hristov, N., Georgiev, M. Offset as an economic operation and a trade practice. // International Scientific Journal "Internauka”. Издатель ООО «Финансовая Рада Украины», Киев, № 10 (32), 2017, pp. 114-117, ISSN 2520-2057).

Hristov, N., Glushkov, P. (2018e). Comparative Analysis of the Management Activity Training Of the Cadets, 
Studying in the Logistic Specializations. // Proceedings of INTCESS2018- 5th International Conference on Education and Social Sciences 5-7 February 2018- Istanbul, Turkey, pp.582-588.

Hristov, N., Glushkov, P. (2018f). Some Aspects Regarding the Display of the Organizational Activity at Work of the Logistic Officers. // Proceedings of INTCESS2018- 5th International Conference on Education and Social Sciences 5-7 February 2018- Istanbul, Turkey, pp.187-193.

Hristov, Neno. (2017d). Policy for Implementation of the Enterprise Architecture as a Tool in Bulgarian Mod. // The University of Sydney, 'History, Problems and Prospects of Development of Modern Civilization' The XX International Academic Congress (Australia, Sydney, 18-20 July 2017) Papers and commentaries Volume XX, ISBN: 978-0-578-84563-7, pp. 821-829.

Madanski, V., Georgiev, M. (2017e). The offset as a specific sort of economic activity. // Scientific journal «Economics and finance». Academic publishing house of the Agricultural University, Priority research areas: Collection of scientific articles, 2017, pp. 4-13, ISBN 978-617-7214-53-2.

Madanski, V., Georgiev, M. (2017f). Study of the effect of offset implementation on technology transfer in the Republic of Bulgaria. // Scientific journal «Economics and finance». Academic publishing house of the Agricultural University, Priority research areas: Collection of scientific articles, 2017, pp. 43-51, ISBN 978-617-7214-53-2.

Terziev, V., Madanski, V., Georgiev, M. (2017g). Offset as an economic operation and a trade practice. // Proceedings of ADVED 2017- 3rd International Conference on Advances in Education and Social Sciences 9-11 October 2017- Istanbul, Turkey. International Organization Center of Academic Research, www.ocerint.org, 2017, pp. 748-753, ISBN: 978-605-82433-0-9.

Terziev, V., Madanski, V., Georgiev, M. (2017h). Offset implementation impact on technology transfer in Bulgaria. // Proceedings of ADVED 2017- 3rd International Conference on Advances in Education and Social Sciences 9-11 October 2017- Istanbul, Turkey .International Organization Center of Academic Research, www.ocerint.org, 2017, pp. 743-747, ISBN: 978-605-82433-0-9.

Terziev, V., Madanski, V., Georgiev, M. (2017i). Offset implementation impact on technology transfer in Bulgaria. // IJAEDU- International E-Journal of Advances in Education, International Organization Center of Academic Research, www.ocerint.org, 3, 2017, N 9, pp. 923-927, e-ISSN: 2411-18.

Terziev, V., Madanski, V., Georgiev, M. (2017j). Offset as an economic operation and a trade practice. // IJAEDU- International E-Journal of Advances in Education, International Organization Center of Academic Research, www.ocerint.org, 3, 2017, N 9, pp. 1051-1055, e-ISSN: 2411-18.

Terziev, V., Nichev, N., Bankov, S. (2016a). Corruption and national security. // Mezhdunarodnyy nauchnnyy zhurnal Inovatsionnaya nauka, №10-3/2016, Chastyakh 3, Ufa, Rossiya, ISSN 2410-6070, s.189-196 (Terziev, V., Nichev, N., Bankov, S. Corruption and national security. // Международный научнный журнал Иновационная наука, №10-3/2016, Частях 3, Уфра, Россия, ISSN 2410-6070, с.189-196).

Terziev, V., Nichev, N., Bankov, S. (2016b). Essence and reasons for the manifestation and basic areas of corruption and government structures for corruption counteraction in Bulgaria. // Sbornik nauchnykh trudov „Novyy vzglyad”: Mezhdunarodnyy nauchnyy vestnik: sbornik nauchnykh trudov. Vypusk 15 / Pod obshch. red. S.S. Chernova. - Novosibirsk: Izdatel'stvo TSRNS, 2016. - 166 s., ISBN 978-500068-714-7, s.116-134 (Terziev, V., Nichev, N., Bankov, S. Essence and reasons for the manifestation and basic areas of corruption and government structures for corruption counteraction in Bulgaria. // Сборник научных трудов „Новый взгляд”: Международный научный вестник: сборник научных трудов. Выпуск 15 / Под общ. ред. С.С. Чернова. - Новосибирск: Издательство ЦРНС, 2016. - 166 с., ISBN 978-5-00068-714-7, c.116-134).

Terziev, V., Nichev, N., Bankov, S. (2016c). National security of the republic of Bulgaria. // Science and practice: Collection of scientific articles. Thoroe-Bowker, Melbourne, Australia, 2016, ISBN 978-09942661-3-2, pp.12-21.

Terziev, V., Nichev, N., Bankov, S. (2016d). Tipichni modeli na razsledvanena koruptsiyata sred politseyski sluzhiteli. // Sbornik dokladi: Godishna universitetska nauchna konferentsiya, 20-21 oktomvri 2016 g., NVU „Vasil Levski“ - Veliko Tarnovo., Nauchno napravlenie "Sotsialni, stopanski i pravni nauki“, 7, 2016, ISSN 1314-1937, str.119-128 (Терзиев, В., Ничев, Н., Банков, С. Типични модели на разследванена корупцията сред полицейски служители. // Сборник доклади: Годишна университетска научна конфреренция, 20-21 октомври 2016 г., НВУ „Васил Левски“ - Велико Търново., Научно направление „Социални, стопански и правни науки“, 7, 2016, ISSN 1314-1937, стр.119-128). 
Terziev, V., Nichev, N., Bankov, S. (2016e). Nakazatelno pravni aspekti na koruptsiyata i ustanoveni praktiki v Balgariya. // Sbornik dokladi: Godishna universitetska nauchna konferentsiya, 20-21 oktomvri 2016 g., NVU „Vasil Levski“ - Veliko Tarnovo., Nauchno napravlenie „Sotsialni, stopanski i pravni nauki“, 7 , 2016, ISSN 1314-1937, str.129-146 (Терзиев, В., Ничев, Н., Банков, С. Наказателно правни аспекти на корупцията и установени практики в България. // Сборник доклади: Годишна университетска научна конфреренция, 20-21 октомври 2016 г., НВУ „Васил Левски“ - Велико Търново., Научно направление „Социални, стопански и правни науки“, 7, 2016, ISSN 1314-1937, стр.129-146).

Terziev, V., Nichev, N., Bankov, S. (2016f). Prilozhenie na efektivna metodika na razsledvane na koruptsiyata sred politseyskite sluzhiteli v Balgariya. // Godishnik na NVU „Vasil Levski“, NVU „Vasil Levski“- Veliko Tarnovo, Izdatelski kompleks na NVU „Vasil Levski”, 2015, ISSN 1312-6148, str.144185 (Терзиев, В., Ничев, Н., Банков, С. Приложение на ефективна методика на разследване на корупцията сред полицейските служители в България. // Годишник на НВУ „Васил Левски“, НВУ „Васил Левски“- Велико Търново, Издателски комплекс на НBУ „Васил Левски”, 2015, ISSN 1312-6148, стр.144-185).

Terziev, V., Nichev, N., Bankov, S. (2016g). Razrabotvane na metodika na razsledvane na koruptsiyata sred politseyskite sluzhiteli v Balgariya. /I XI Mezhdunarodnoy nauchnoy konferentsii "Innovatsii v tehnologiyah i obrazovanii“, 18-19 Marta 2016 g., Sbornik statey: chasty 3, Belovo- Veliko-tayrnovo, 2016, Kuzbasskiy gosudarstvennayy tehnicheskiy universitet imeni T.F. Gorbacheva Velikotayrnovskiy universitet im. Svyatayh. Kirilla i Mefodiya Filial KuzGTU v g. Belovo Vaysshaya shkola agrobiznesa i razvitiya regionov, Plovdiv, 2016, s.413-422, ISBN 978-5-906888-03-7 (Терзиев, В., Ничев, Н., Банков, С. Разработване на методика на разследване на корупцията сред полицейските служители в България. // XI Международной научной конференции „Инновации в технологиях и образовании“, 18-19 Марта 2016 г., Сборник статей: часть 3, Белово- Велико-тырново, 2016, Кузбасский государственный технический университет имени Т.Ф. Горбачева Великотырновский университет им. Святых. Кирилла и Мефодия Филиал КузГТУ в г. Белово Высшая школа агробизнеса и развития регионов, Пловдив, 2016, с.413-422, ISBN 978-5-906888-03-7).

Terziev, V., Nichev, N., Bankov, S. (2016h). Prilozhenie na efektivna metodika na razsledvane na koruptsiyata sred politseyskite sluzhiteli v Balgariya. // Sbornik dokladi: Parva nauchna konferentsiya po sotsialno predpriemachestvo. Saveti, umeniya i instrumenti za konsultirane na sotsialnite predpriemachi, Proekt : Umeniya za biznes konsultanti v oblastta na sotsialnoto predpriemachestvo, International scientific conference 29 September 2016, Plovdiv, Bulgaria, Agraren Universitet Plovdiv, 2016, ISBN 978-954-517-249-6 (CD), ISBN 978-954-517-250-2 (Print), str.177-204 (Терзиев, В., Ничев, Н., Банков, С. Приложение на ефрективна методика на разследване на корупцията сред полицейските служители в България. // Сборник доклади: Първа научна конференция по социално предприемачество. Съвети, умения и инструменти за консултиране на социалните предприемачи, Проект : Умения за бизнес консултанти в областта на социалното предприемачество, International scientific conference 29 September 2016, Plovdiv, Bulgaria, Аграрен Университет Пловдив, 2016, ISBN 978-954-517-249-6 (CD), ISBN 978-954-517-250-2 (Print), cтр.177-204).

Nichev, N. (2017k). Ofsetna politika na stranite ot Evropeyskiya Sayuz. Spisanie za nauka „Novo znanie”, Akademichno izdatelstvo „Talant", Visshe uchilishte po agrobiznes i razvitie na regionite, Plovdiv, Vol 6, No 1, 2017, str. 121-128, ISSN 2367-4598 (Online), ISSN 1314-5703 (Print) (Ничев, Н. Офрсетна политика на страните от Европейския Съюз. Списание за наука „Ново знание”, Академично издателство „Талант“, Висше училище по агробизнес и развитие на регионите, Пловдив, Vol 6 , No 1, 2017, стр. 121-128, (Online) ISSN 2367-4598, (Print) ISSN 1314-5703).

Nichev, N. (2017l). Perspektivi za izpolzvane na ofsetnite sdelki. Spisanie za nauka „Novo znanie”, Akademichno izdatelstvo „Talant", Visshe uchilishte po agrobiznes i razvitie na regionite - Plovdiv, Vol 6, No 1, 2017: pp. 129-135, (Online) ISSN 2367-4598, (Print) ISSN 1314-5703 (Ничев, Н. Перспективи за използване на офсетните сделки. Списание за наука „Ново знание”, Академично издателство „Талант“, Висше училище по агробизнес и развитие на регионите Пловдив, Vol 6, No 1, 2017: pp. 129-135, (Online) ISSN 2367-4598, (Print) ISSN 1314-5703).

Kanev, D.,Terziev. V. (2017m). Behavioral economics: development, condition and perspectives. // IJASOSInternational E-Journal of Advances in Social Sciences, Vol. III, Issue 8, e-ISSN: 2411-183X.

Kanev, D.,Terziev. V. (2017n). Behavioral economics: development, condition and perspectives. // Proceedings of SOCIOINT 2017- 4th International Conference on Education, Social Sciences and 
Humanities 10-12 July 2017- Dubai, UAE, ISBN: 978-605-82433-1-6.

Sotirov, B., Terziev, V. (2015a). Predizvikatelstva i perspektivi pred obuchenieto po tehnologichni distsiplini. // Parva mezhdunarodna nauchna konferentsiya „Predizvikatelstva pred savremennite organizatsii, svarzani s postigane na ustoychivost - znanie i inovatsii v upravlenieto i funktsioniraneto",Plovdiv. ISBN 978-619-7246-04-9 (DVD), ISBN 978-619-7246-06-3 (e-book).

Sotirov, B., Terziev, V. (2015b). Challenges and perspectives to the training in technological subjects. // Book of Abstracts: First International Scientific Conference "Sustainability Challenges in Modern Organizations - Knowledge \& Innovation in Management \& Operation", ISBN 978-619-7246-03-2 (DVD), ISBN 978-619-7246-05-6 (e-book).

Terziev. V. (20170). National security of the republic of Bulgaria. // The Chinese Journal of International Politics, №1(10), ISSN 1750-8916.

Terziev. V. (2016i). Human resource management systems in security and defense: social policies for social activities. // XXXII Mezhdunarodnaya nauchno-prakticheskaya konferentsiya, Evraziyskiy soyuz uchenayh (ESU), Ezhemesyachnayy nauchnayy zhurnal № 12 (33)/ 2016 Chasty 1, Moskva 30.12.2016g., ISSN 2411-6467.

Terziev. V. (2017p). Entry Opportunities in the Bulgarian Military - Educational System and Ensuring of Civil Rights. // 3rd Central and Eastern European LUMEN International Scientific Conference New Approaches in Social and Humanistic Sciences 8-10 June 2017 | Chisinau, Republic of Moldova, ISBN: 978-973-166-461-3.

Terziev. V. (2017q). National security of the republic of Bulgaria. // International Journal of Management and Applied Science, Volume-3, Issue-4, ISSN: 2394-7926.

Terziev, V., Vezieva. V., Arabska, A. (2016j). Balgarskite universiteti i vazmozhnostite na Operativna programa „Nauka i obrazovanie za inteligenten rastezh". // Mezhdunarodna nauchna konferentsiya „Obrazovanie, nauka, ikonomika i tehnologii“ 23-24 yuni 2016 g. Akademichno spisanie „Upravlenie i obrazovanie“ Tom XII(1) 2016, ISSN 1312-6121.

Terziev, V., Manolov.D. (2016k). Sazdavane na dobra organizatsionna sreda za nauchnoizsledovatelska deynost (Creation of good organizational environment for scientific research activity), Aktual'nyye problemy globalizatsii. // Saloniki, Gretsiya (Actual problems of globalization, August 29, 2016, Thessaloniki, Greece), Scientific journal „ECONOMICS AND FINANCE“, Actual problems of globalization - Collection of scientific articles, ISBN 978-617-7214-34-1.

Terziev, V., Minev, R., Sotirov, B., Ivanov, K. (2016I). Vazmozhnosti za izgrazhdane na tsentar za kompetentnost $v$ Severen tsentralen rayon na Republika Balgariya. // Godishna universitetska nauchna konferentsiya, 20-21 oktomvri 2016 g. NVU „Vasil Levski“- Veliko Tarnovo. Sbornik dokladi tom 2, Nauchni napravleniya „Prirodomatematicheski nauki” i „Tehnicheski nauki”, ISSN 1314-1937.

Terziev. V., Kanev, D. (2017r). Education and Behavioural Failures. // Proceedings of ADVED 2017- 3rd International Conference on Advances in Education and Social Sciences 9-11 October 2017- Istanbul, Turkey, ISBN: 978-605-82433-0-9.

Terziev, V, Madanski, V. (2017s). Development of military education system in Bulgaria (Razvitie na voennoobrazovatelnata sistema $v$ Balgariya). // Topical questions of contemporary science, United States of America 2017, ISBN 978-0-9988732-1-3.

Terziev, V, Madanski, V. (2017t). Guidelines for development of military education system in Bulgaria (Nasoki za razvitie na voennoobrazovatelnata sistema na Balgariya). // Topical questions of contemporary science, United States of America 2017, ISBN 978-0-9988732-1-3.

Terziev, V, Madanski, V. (2017u). Guidelines for development of military education system in Bulgaria. // Proceedings of the VII International Academic Congress "Fundamental and Applied Studies in EU and CIS Countries" (United Kingdom, Cambridge, England, 26-28 February 2017). Volume VII. Cambridge University Press, 2017, ISBN: 978-0-875-83597-4.

Terziev, V, Madanski, V., Kanev, D. (2017v). Entry opportunities in the bulgarian military-educational system and ensuring of civil rights. // Proceedings of SOCIOINT 2017- 4th International Conference on Education, Social Sciences and Humanities 10-12 July 2017- Dubai, UAE, ISBN: 978-605-82433-1-6.

Terziev, V, Madanski, V., Kanev, D. (2017w). Entry opportunities in the bulgarian military-educational system and ensuring of civil rights. // IJAEDU- International E-Journal of Advances in Education, Vol. 3, Issue 
8, August 2017, e-ISSN:2411-1821.

Terziev, V, Madanski, V., Kanev, D. (2017x). Entry opportunities in the Bulgarian military-educational system. // Sport, Education and Society, Issue 8 (2), Volume 22. Taylor \& Francis, Print ISSN: 1357-3322 Online ISSN: 1470-1243.

Terziev, V, Madanski, V., Kanev, D. (2017y). Condition and capabilities of the military-educational system of the Republic of Bulgaria. // Sport, Education and Society, Issue 8 (2), Volume 22. Taylor \& Francis, Print ISSN: 1357-3322 Online ISSN: 1470-1243.

Terziev, V, Madanski, V., Kanev, D. (2017z). Directions for improvement of the military-educational system and its contribution for strengthening national security and the defence of the country. // Sport, Education and Society, Issue 8 (2), Volume 22. Taylor \& Francis, Print ISSN: 1357-3322 Online ISSN: 1470-1243.

Terziev, V., N.Nichev. $(2016 \mathrm{~m})$. Ikonomicheski harakteristiki na ofestnite sdelki s otrbranitelni produkti. // Scientific journal „Economics and Finance”, Problems of development modern science: Theory and practice - Collection of scienfic articles, pp.101-106.

Terziev. V., N.Nichev. (2017). Osnovni harakteristiki na kompensaciite $v$ tyrgoviqta s otbrana. // Proceedings of SOCIOINT 2017- 4th International Conference on Education, Social Sciences and Humanities, pp.661-666. 